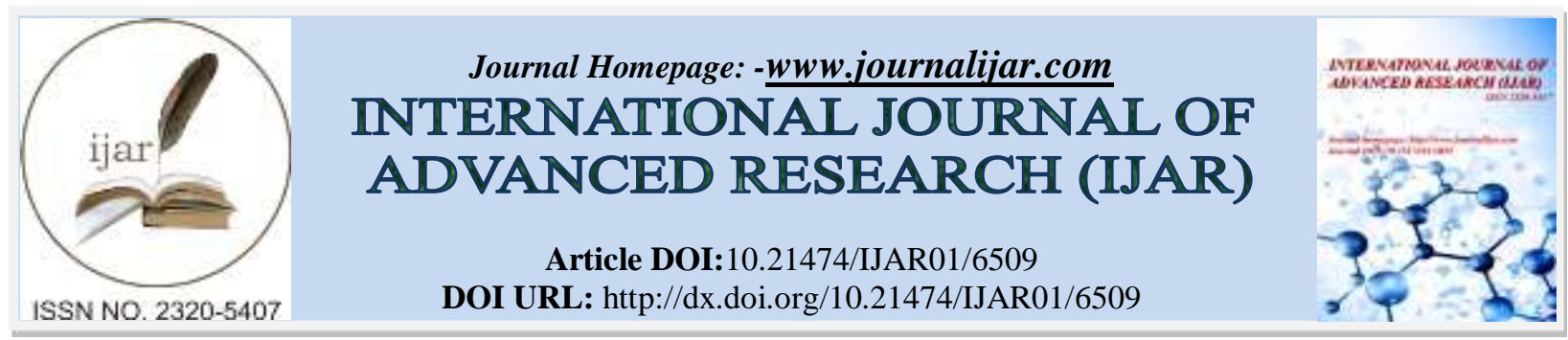

RESEARCH ARTICLE

\title{
NEST CHARACTERISTICS AND NESTING SUCCESS OF THE INDIAN PIED MYNA (GRACUPICA CONTRA) IN JAMMU REGION (J\&K).
}

\author{
Meena Kumari ${ }^{1}$, Prof. D. N. Sahi ${ }^{2}$ and Prof. Seema Langer ${ }^{3}$. \\ 1. Research Scholar, Department of Zoology, University of Jammu. \\ 2. Professor, Department of Zoology, University of Jammu. \\ 3. Head, Department of Zoology, University of Jammu.
}

\section{Manuscript Info}

\section{Manuscript History}

Received: 11 December 2017

Final Accepted: 13 January 2018

Published: February 2018

\section{Key words:-}

Indian Pied Myna, Nest

characteristics, Tampering, Nesting

success.

\begin{abstract}
The nest characteristics and nesting success of the Indian Pied Myna (Gracupica contra) were studied from May, 2013 to September, 2015 in Jammu region of J\&K State. A total of 55 nests were studied. Nesting started in April and continued till August. Fourteen plant species were used for nesting and maximum number of nests was found on Mangifera indica. The nest was quite untidy but the innermost chamber was examined to be flask-shaped and nest constructed by plant, animal and artificial matter by both sexes. The mean nest hole diameter and depth was $8.17 \pm 1.23 \mathrm{~cm}$ and $14.10 \pm 1.52 \mathrm{~cm}$ respectively. Height of nests from ground ranged from 1.54-11.68 $\mathrm{m}$ and had a significant effect on nesting success. The maximum number of nests were recorded at height range of 5.1-7.5 $\mathrm{m}$ with success rate of $42.85 \%$. Tampering with nest and nesting tree was the major cause of nest failure during present study.
\end{abstract}

Copy Right, IJAR, 2018,. All rights reserved.

\section{Introduction:-}

Nesting play a very significant role in the life cycle of bird as it is ultimately related to reproductive success. In some species of birds, reduced reproductive success has been recorded due to selection of poor nesting sites (Frederick 1986, 1987a). A good nesting site generally provides easy access to food, presence of suitable nesting material, protection from unsuitable weather condition and predators. Moreover, it has a direct effect on reproductive success of a species through its influence on the production of young (Martin and Roper, 1988). In addition to architecture of nest should be such that helps to survive the young against unfavorable conditions. Indian Pied Myna (Gracupica contra) is a starling belonging to family Sturnidae found in Indian subcontinent and in Bangladesh, Myanmar, Western-Indonesia, Thailand, Malaysia (Ali, 2002 and Feare and Craig, 2010). The genus Gracupica has two species viz. Black-Collared Starling (Gracupica nigricollis) and Indian Pied Myna (Gracupica contra). The Indian Pied Myna is one of the most common species of birds found in northern and eastern India. It is recognized by yellowish bill with orange-reddish base. Skin around the eyes is orange-reddish. The plumage is complementary black and white. This species is socialable and chiefly terrestrial insectivorous but also feed upon fruits and berries of Ficus too. It is found in flocks during non- breeding season and many times found associated with other mynas, near villages and human habitations. 


\section{Materials and methods:-}

Study Area:

Study pertaining to the nesting ecology of Indian Pied Myna was carried out in Jammu region. As the habitat elements vary considerably within the Jammu region, the study area was categorized into six stations.

Stn-1 GhoManhasa: The latitude and longitude of this station are $32^{\circ} 43^{\prime} 39.59^{\prime \prime} \mathrm{N}$ and $74^{\circ} 45^{\prime} 41.36^{\prime \prime}$ E respectively and it is located at an altitude of $311 \mathrm{msl}$. The village is at the distance of $10.9 \mathrm{~km}$ from Jammu city in Marh tehsil. The main source of water at this station is GhoManhasa stream which is itself an off-shoot of the river Chenab. The major area is under cultivation.

Stn-2 Bishnah: This station is located $32^{\circ} 62^{\prime} \mathrm{N}$ latitude and $74^{\circ} 87^{\prime} \mathrm{E}$ longitude, at a distance of $14 \mathrm{~km}$ from Jammu city. It is located at an altitude of $292 \mathrm{~km}$.

Stn-3 Sarore: The station lies between $32^{\circ} .627 \mathrm{~N}$ latitude and $74.889 \mathrm{E}$ longitude.

Stn-4 Gharana village, R. S. Pura: This station is situated between $32^{\circ} 36^{\prime} 51.52^{\prime \prime} \mathrm{N}$ latitudes and $74^{\circ} 38^{\prime} 58.15^{\prime \prime}$ E longitudes. It is located at an elevation of $251 \mathrm{msl}$. It is at a distance of $35 \mathrm{~km}$ from the Jammu city in Ranbir Singh Pura tehsil. The famous Gharana wetland lies on the west of village close to Indo-Pak border. It provides a good habitat for water birds and also acts as an important wintering ground for migratory birds from Siberia.

Stn-5 R. S. Pura: This station is positioned at a latitude of 32 $36^{\prime} 27.56^{\prime \prime} \mathrm{N}$ and a longitude of $74^{\circ} 43^{\prime} 57.29^{\prime \prime}$ E with an elevation of $271 \mathrm{msl}$. It is at a distance of $31 \mathrm{~km}$ from Jammu city. The main source of water at this station is Ranbir Canal.

Stn-6 New University Campus: It lies between the latitudes of $32^{\circ} 67^{\prime} \mathrm{N}$ and the longitudes of $76^{\circ} 50^{\prime} \mathrm{E}$ with an altitude of $340 \mathrm{msl}$. It is at a distance of about $2 \mathrm{~km}$ from Jammu city. It is situated in the heart of the city and encloses departments, residential quarters, canteens, botanical garden, zoological park and cactus garden. Vegetation is mainly dominated by tree canopy.

\section{Methodology:-}

In order to record nesting ecology of Indian Pied Myna periodic survey were carried out in study area. Data were collected and analyzed as per standard methodology available from the ornithological study. The nests were located by observing the behaviours of birds (moving with nesting material, food etc). An active nest was confirmed if adult were seen performing breeding activities (nest building or renovation, incubation, feeding the youngs in or adjacent of nest). The method for determining nest-site selection is similar to that of already established in a number of nestsite selection studies (e.g., Bechard et al, 1990; Hullsieg and Becker 1990). Observations were made with the help of field binocular (Bushnell 7 X 50 U.S.A. made) or by direct visual method as required. For each nest shape, size and structure were recorded. Nesting plants were identified upto species level. Variable measured includes nest and nest site characteristics. Detailed description of variable and method of measurement are given in Table-1.

Nesting success was calculated according to Shah (1984) and Fazili (2002) as follows:

$$
\frac{\mathrm{NS}}{\mathrm{NS}+\mathrm{NU}} \times 100
$$

Where NS $=$ Number of Successful nests (i.e., nests in which atleast one nestling survived). NU= Number of Unsuccessful nests.

\section{Result and Discussion:- \\ Nesting Season:}

The nesting season of Indian Pied Myna (Gracupica contra) was commenced in April and continued till August in the study area with peak breeding period in the month of May and June. During the study period, a total of 82 nests were found in the six study station out of which 55 were studied thoroughly.

\section{Selection of Nesting Site:}

Both the partners were observed to equally participate in selection of nesting site preferably near to water which acts as key factor for nesting site selection. Height of the tree and tree species selected by bird were considered as an 
important factor in the nesting site selection. Pied Myna preferred different tree species for nest construction and most of the nesting tree were found in vicinity of different water body viz. canals, streams, ponds and marshes.

A total of 82 nests were located out of which 55 were studied thoroughly. 3 nests were found on electric pole while 79 were found on trees. The selection of trees and poles for nesting is in agreement with that of Kailey (1973) and Tyagi and Lamba (1984). During present study work, about 14 species of trees were utilized by Indian Pied Myna for nesting (Table-2). Among these trees, maximum number of nests were found on Mangifera indica by $16.45 \%$ followed by Eucalyptus globulus with $11.39 \%$ while $2.53 \%$ on Neolamarckia cadamba. In few cases, some of the previous nesting trees and even same branch of nest location were utilized again for nest breeding season. The nests of Indian Pied Myna were solitary and mostly found in close vicinity of each other but in few cases two nests were seen on same. Ali (2002) recorded 3 or 4 nests on a single tree. Whistler (1928) however observed colonial nesting in Indian Pied Myna.

\section{Nest Construction:}

After selecting a suitable site for nesting, both the members of the breeding pair actively participate in the nest construction, as both the partners were seen bringing the nesting material together at the nest sites. Tyagi and Lamba (1984) and Kumar (2006) also made similar observations. The nest was constructed mainly by using grass roots, grass stem, wheat straw, twigs, weed plants, dry leaves of different plants, feather, jute threads, pieces of cloths, cotton, rubber band, polythene, wrappers, knitted thread as well as human and animal hairs. George (1970), Ali and Ripley (1972), Kailey (1973), Tyagi and Lamba (1984) and Kumar (2006) recorded similar type of nesting material used by Indian Pied Myna. Moreover, nests were mostly build in between forked branches at different position viz. middle, periphery, a top or at the lower side canopy of nesting tree.

On closer examination, the outer appearance of the nest was quite untidy but the innermost chamber was examined to be flask-shaped having a globular egg chamber with narrow lateral opening. Egg chamber was smooth lined with softer material like thread and feather and found to be big enough to accommodate the fully developed young ones. A good size of nest having trailing rag cloth, grass twigs, plastic rope etc., clearly indicates the presence of nest from a long distance.

\section{Nest and Nest site characteristics:}

After completion of breeding season, various nest and nest site characteristics were noted down (Table-3). Nest and nest site variables were collected from 55 nests that had good accessibility. Nest hole diameter varied from 5.50$10.00 \mathrm{~cm}$ with mean $8.17 \pm 1.23 \mathrm{~cm}$. The depth of nest varied from $11.20-17.50 \mathrm{~cm}$ with mean of $14.10 \pm 1.52 \mathrm{~cm}$. Kailey (1973) reported that nest hole diameter varied from 5 to $10 \mathrm{~cm}$. Feare and Craig (2010) recorded nest hole diameter varied from 6 to $8 \mathrm{~cm}$. The nests were placed at mean height of $6.37 \pm 2.50 \mathrm{~m}$ ranging from $1.54-11.68 \mathrm{~m}$ above the ground. This finding is in agreement with Dewar (1929) who also reported the nest height between 3 to 12 m. Tyagi and Lamba (1984), Pandey (1991) and Feare and Craig (2010) recorded height of the nest from the ground between 5 to $15 \mathrm{~m}$. Moreover, height of the nesting tree varied between 3.15-20.50 $\mathrm{m}$ and an average height was $9.48 \pm 3.88 \mathrm{~m}$. The average distance of nest from nearest agricultural land was $54.51 \pm 106.83 \mathrm{~m}$, from water body was $193.00 \pm 173.53 \mathrm{~cm}$, from nearest perch site was $13.80 \pm 324 \mathrm{~m}$, human habitation was $193.84 \pm 301.00 \mathrm{~m}$ and road was recorded to be $156.74 \pm 340.30 \mathrm{~m}$ (Table-3).

\section{Nesting Success with respect to height and placement of nests:}

The nests were found to be built on trees upto height of 12.5 meter and highest number of nest were recorded at height range of 5.1-7.5 m with maximum success rate of $42.85 \%$ because this height range was found to be the most favoured for building nest while least number of nest were found between the height range of $0-2.5 \mathrm{~m}$ with $15.38 \%$ of unsuccessful nest (Table-4) as they were more vulnerable to predation. Moreover, maximum successful nests were found at periphery of the tree with percentage distribution of $42.8 \%$ and least number of successful nests were recorded at the lower tree canopy by $4.76 \%$ (Table-5) because the nests present at lower and top of tree canopy were more prone to predation, therefore Pied Myna preferred to construct nest at periphery in between forked branches to protect it from ground predators. Hence, height of the nest from the ground and nest placement on tree plays an important role in the nesting success.

\section{Nesting success and Nest loss:}

Nesting success can be defined as the percentage of nests in which hatching occurred. During breeding season, the nesting success of Indian Pied Myna has been recorded for three successive years. Out of 55 nests, 42 (76.36\%) 
nests were found to be successful and 13 were unsuccessful because of various reasons like desertion $(\mathrm{n}=2)$, predation $(n=2)$, tampering with nests $(n=5)$ and some other factors $(n=4)$ (Table-7). Thus, tampering with nest and nest site was the major cause of nest failure for this species characterized by complete loss of eggs or nestlings in the present study area. In addition to nesting success were recorded to be maximum in year 2014 (85.71\%) and minimum in year $2013(68.18 \%)$ (Table-6).

\section{Conclusion:-}

Thus, from the present study it was concluded that Indian Pied Myna preferred fourteen different tree species with height range of 3.15-20.50 m and most preferable height range was $5.1-7.5 \mathrm{~m}$ because it provided stability and protection to the nest from predator. In addition to, tampering with nest and nesting tree was the major cause of nest failure because human disturbances especially children tamper with nest for fun purposes and cutting of nesting trees during breeding season. So, Indian Pied Myna was found to shift their nesting site from trees to electric poles.

\section{Acknowledgement:-}

The authors are highly acknowledged to the Department of Zoology, University of Jammu for providing the necessary facilities to carry out the study.

Table1:- Description of nest and nest site characteristics variables of Indian Pied Myna (Gracupica contra) in Jammu region:

\begin{tabular}{|l|l|l|}
\hline S.NO & Code & Variable \\
\hline 1 & NHDM & Nest hole diameter $(\mathrm{cm})$ \\
\hline 2 & NDEP & Nest depth $(\mathrm{cm})$ \\
\hline 3 & HNGD & Height of nest from the ground $(\mathrm{m})$ \\
\hline 4 & HTTR & Height of tree \\
\hline 5 & DNNT & Distance from the nearest agricultural land $(\mathrm{m})$ \\
\hline 6 & DNWB & Distance from nearest water body $(\mathrm{cm})$ \\
\hline 7 & DNPS & Distance from nearest perch site $(\mathrm{cm})$ \\
\hline 8 & DNHH & Distance from nearest human habitation $(\mathrm{m})$ \\
\hline 9 & DNRD & Distance from road $(\mathrm{m})$ \\
\hline
\end{tabular}

Table2:- List of trees used by Indian Pied Myna (Gracupica contra) for nesting in study area.

\begin{tabular}{|c|c|c|c|c|c|}
\hline S. No. & Botanical name & Local name & Family & $\begin{array}{l}\text { Number of } \\
\text { nests }\end{array}$ & $\%$ \\
\hline 1 & Zizyphusmauratiana & Beri & Rhamnaceae & 8 & 10.12 \\
\hline 2 & Acacia nilotica & Kikar & Mimosaceae & 7 & 8.86 \\
\hline 3 & Ficusreligosa & Peepal & \multirow[t]{3}{*}{ Moraceae } & 4 & 5.06 \\
\hline 4 & Ficusbenghalensis & Bargad & & 3 & 3.79 \\
\hline 5 & Morus alba & Mulberry & & 4 & 5.06 \\
\hline 6 & Populusnigra & Poplar & Saliaceae & 5 & 6.33 \\
\hline 7 & Mangiferaindica & Mango (Aam) & Anacardiaceae & 13 & 16.45 \\
\hline 8 & Psidiumguajava & Guava & \multirow[t]{3}{*}{ Myrtaceae } & 5 & 6.33 \\
\hline 9 & Syzygiumcumini & Jamun & & 5 & 6.33 \\
\hline 10 & Eucalyptus globulus & Safeda & & 9 & 11.39 \\
\hline 11 & Meliaazedarach & Dhrek & Meliaceae & 6 & 7.59 \\
\hline 12 & Dalbergiasisso & Talli & Papilionaceae & 5 & 6.33 \\
\hline 13 & Neolamarckiacadamba & Kadam & Rubiaceae & 2 & 2.53 \\
\hline 14 & Albizialebbeck & Siris & Fabaceae & 3 & 3.79 \\
\hline
\end{tabular}

Table3:- Nest and nesting site characteristics of Indian Pied Myna (Gracupica contra) in the study area $(\mathbf{n}=55)$.

\begin{tabular}{|l|l|l|l|}
\hline Code & \multicolumn{1}{|c|}{ Variable } & Mean \pm SD & Range \\
\hline NHDM & Nest hole diameter $(\mathrm{cm})$ & $8.17 \pm 1.23$ & $5.50-10.00$ \\
\hline NDPT & Nest depth $(\mathrm{cm})$ & $14.10 \pm 1.52$ & $11.20-17.50$ \\
\hline HNGD & Height of Nest from ground $(\mathrm{m})$ & $6.35 \pm 2.50$ & $1.54-11.68$ \\
\hline
\end{tabular}




\begin{tabular}{|l|l|l|l|}
\hline HTTR & Height of tree $(\mathrm{m})$ & $9.48 \pm 3.88$ & $3.15-20.50$ \\
\hline DNNT & Distance from Agricultural land $(\mathrm{m})$ & $54.51 \pm 106.83$ & $1.26-540.00$ \\
\hline DNWB & Distance from nearest water body $(\mathrm{cm})$ & $193.00 \pm 173.53$ & $22.4-784.00$ \\
\hline DNPS & Distance from nearest perch site $(\mathrm{cm})$ & $76.49 \pm 54.21$ & $13.80-324.00$ \\
\hline DNHH & Distance from human habitation $(\mathrm{m})$ & $193.84 \pm 301.07$ & $7.36-1523$ \\
\hline DNRD & Distance from road(m) & $156.74 \pm 340.30$ & $1.23-1506$ \\
\hline
\end{tabular}

Table 4:-Nesting success recorded with respect to height of nests in Indian Pied Myna (Gracupica contra).

\begin{tabular}{|l|l|l|l|l|l|l|}
\hline \multirow{2}{*}{$\begin{array}{l}\text { Height range } \\
(\mathbf{c m})\end{array}$} & \multicolumn{2}{l|}{ Total no. of nests } & \multicolumn{2}{l|}{ No. of successful nests } & \multicolumn{2}{l|}{ No. of unsuccessful nests } \\
\cline { 2 - 7 } & $\mathrm{N}$ & $\%$ & $\mathrm{~N}$ & $\%$ & N & $\%$ \\
\hline $0-2.5 \mathrm{~m}$ & 3 & 5.45 & 1 & 2.38 & 2 & 15.38 \\
\hline $2.6-5.0 \mathrm{~m}$ & 14 & 25.45 & 11 & 26.19 & 3 & 23.07 \\
\hline $5.1-7.5 \mathrm{~m}$ & 20 & 36.36 & 18 & 42.85 & 2 & 15.38 \\
\hline $7.6-10.0 \mathrm{~m}$ & 12 & 21.81 & 8 & 19.04 & 4 & 30.76 \\
\hline $10.1-12.5 \mathrm{~m}$ & 6 & 10.90 & 4 & 9.5 & 2 & 15.38 \\
\hline Total & $\mathbf{5 5}$ & $\mathbf{9 9 . 9 7}$ & $\mathbf{4 2}$ & $\mathbf{9 9 . 9 6}$ & $\mathbf{1 3}$ & $\mathbf{9 9 . 9 7}$ \\
\hline
\end{tabular}

Table 5:-Nesting success with respect to placement of nest with in different tree in Indian Pied Myna (Gracupica contra)

\begin{tabular}{|l|l|l|l|l|l|l|}
\hline \multirow{2}{*}{$\begin{array}{l}\text { Placement of nest } \\
\text { in tree }\end{array}$} & \multicolumn{2}{|l|}{ Total no. of nests } & \multicolumn{2}{l|}{ No. of successful nests } & \multicolumn{2}{l|}{ No. of unsuccessful nests } \\
\cline { 2 - 7 } & $\mathbf{N}$ & $\mathbf{\%}$ & $\mathbf{N}$ & $\mathbf{\%}$ & $\mathbf{N}$ & $\mathbf{\%}$ \\
\hline Middle (in b/w fork) & 19 & 34.55 & 15 & 35.71 & 4 & 30.76 \\
\hline Top & 7 & 12.72 & 5 & 11.90 & 2 & 15.38 \\
\hline Lower & 4 & 7.27 & 2 & 4.76 & 2 & 15.38 \\
\hline Periphery & 25 & 45.45 & 20 & 47.61 & 5 & 38.46 \\
\hline Total & $\mathbf{5 5}$ & $\mathbf{9 9 . 9 9}$ & $\mathbf{4 2}$ & $\mathbf{9 9 . 9 8}$ & $\mathbf{1 3}$ & $\mathbf{9 9 . 9 8}$ \\
\hline
\end{tabular}

Table 6:-Percentage nesting success of Indian Pied Myna (Gracupica contra) recorded during three consecutive years.

\begin{tabular}{|l|l|l|l|l|}
\hline Year & $\begin{array}{l}\text { Total no. of } \\
\text { nest studied }\end{array}$ & No. of successful nests & No. of unsuccessful nests & $\begin{array}{l}\text { Total nesting } \\
\text { success (\%) }\end{array}$ \\
\hline 2013 & 22 & 15 & 7 & 68.18 \\
\hline 2014 & 14 & 12 & 2 & 85.71 \\
\hline 2015 & 19 & 15 & 4 & 78.94 \\
\hline Total & $\mathbf{5 5}$ & $\mathbf{4 2}$ & $\mathbf{1 3}$ & $\mathbf{7 6 . 3 6}$ \\
\hline
\end{tabular}

Table 7:-Nest loss in case Indian Pied Myna (Gracupica contra) due to various causative factors $(\mathrm{n}=55)$ for three consecutive years.

\begin{tabular}{|c|c|c|c|c|c|c|c|}
\hline \multirow[b]{2}{*}{ Year } & \multirow[b]{2}{*}{$\begin{array}{l}\text { Total } \\
\text { nests } \\
\text { studied }\end{array}$} & \multirow[b]{2}{*}{$\begin{array}{l}\text { Failed } \\
\text { nests }\end{array}$} & \multicolumn{5}{|c|}{ Number of nest loss to } \\
\hline & & & Desertion & Depredation & Starvation & $\begin{array}{l}\text { Tampering } \\
\text { with nest or } \\
\text { nesting tree }\end{array}$ & $\begin{array}{l}\text { Other reasons } \\
\text { (wind, rainfall) }\end{array}$ \\
\hline 2013 & 22 & 7 & - & 1 & - & 2 & 4 \\
\hline 2014 & 14 & 2 & 1 & - & - & 1 & - \\
\hline 2015 & 19 & 4 & 1 & 1 & - & 2 & - \\
\hline Total & 55 & 13 & 2 & 2 & ( & 5 & 4 \\
\hline
\end{tabular}




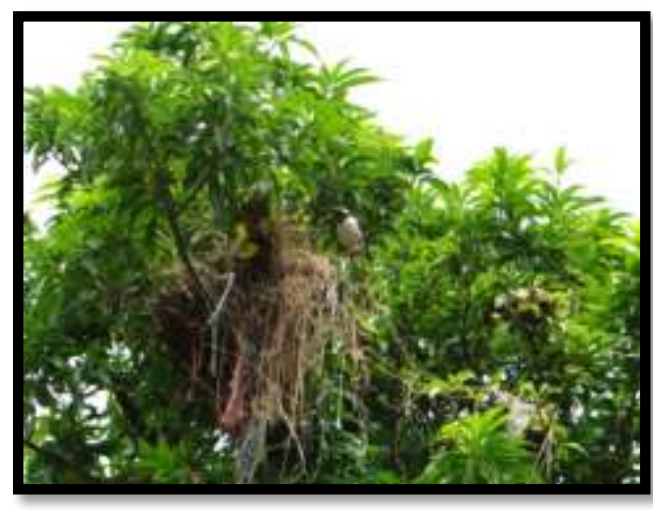

Fig. 1:-Nest on Mangifera indica

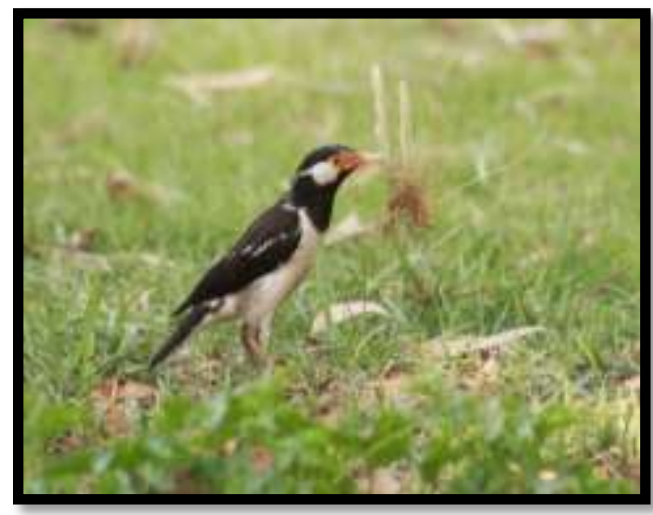

Fig. 3:-Indian Pied Myna collecting nesting material

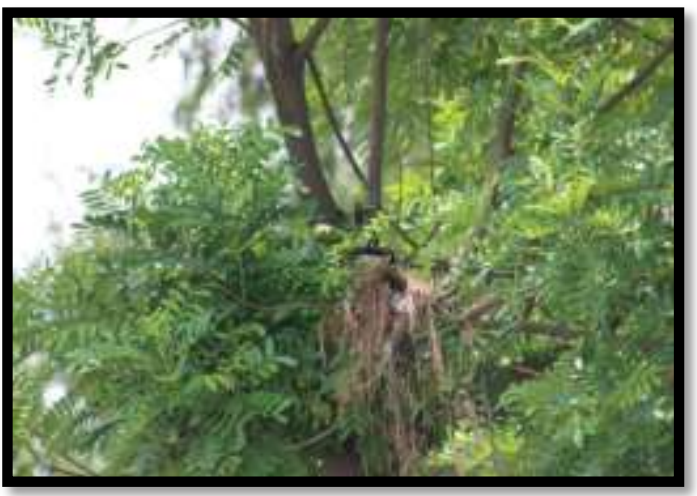

Fig. 2:-Nest on Albizia lebbeck

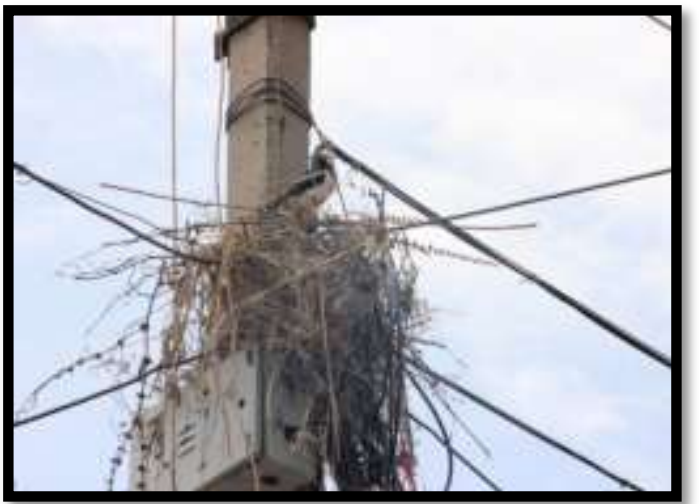

Fig. 4:-Nest on Electric pole

\section{References:-}

1. Ali, S. and Ripley. S.D. 1987. Compact handbook of the birds of India and Pakistan. Oxford Univ. Press, New Delhi.

2. Ali, S. (2002). The book of Indian Birds. Thirteenth ed. Oxford University Press.

3. Ali, S. and Ripley, S.D. (1972). "Handbook of the birds of India and Pakistan. Vol.5. Oxford University Press, Bombay. P. 1-276.

4. Bechard, M.J., Knight, R.L., Smith, D.G. and R. E. Fitzner, 1990. Nest sites and habitat of sympatric Hawks (Buteospp.) in Washington. J. Field Ornithol., 61: 159-170.

5. Dewar, D. (1929). "Indian Bird's nest". Thacker, Spink and Co. Calcutta and Bombay. p. 1-117.

6. Fazili, M.F. 2002. Studies on annual cycle of some birds of Wular Lake, Kashmir. Ph.D Thesis submitted to University of Kashmir.

7. Feare, C. and Craig, A. (2010). Helm identification of Starlings and Mynas illustrated by Barry Croucher, Chris Shield and KarmolKomolphalin. pp.167.

8. Frederick, P.C. (1986). Conspecefic nest takeovers and egg destruction by White Ibises. Wilson Bull 98:156157.

9. Frederick, P.C. (1987a). Choronictidallyinduced nest failure in a colony of White Ibises. Condor 89: 413-419.

10. George, N.J. (1970). The Pied Myna, Sturnus contra L. in Bombay. J. Bomb. Nat. Hist. Soc., 68: 243.

11. Hullsieg, C. and D. M. Becker, 1990. Nest site habitat selected by Merlins in south-eastern Montana. Condor, 92: 688-694.

12. Kailey, J.S. (1973). Studies on the biology of Pied Myna, Sturnus contra. M.Sc thesis, Punjab Agricultural University, Ludhiana.

13. Kumar, S. (2006). Diversity of avian and mammalian fauna of district Kathua, J\&K. Ph.D. Thesis, submitted to University of Jammu.

14. Martin, T.E. and Roper, J.J. (1988). Nest predation and nest-site selection of a western population of the Hermit Thrush. Condor, 90: 51-57. 
15. Pandey, D.N. (1991). Nesting habitat selection by the Pied myna, Sturnus contra Linn. 88: 285-286.

16. Shah, G.M. (1984). Birds of Hokersar: food, feeding and breeding biology of resident and non-resident birds. Ph.D Thesis, P.G. Department of Zoology. University of Kashmir.

17. Tyagi, A.K. and Lamba, B.S. (1984). A contribution to the breeding biology of two Indian Mynas, Rec. Zool. Surv. India 55: 12-34.

18. Whistler, H. (1928). "Popular handbook of Indian birds". Ist edition. Oliver and Boyd. Edinburgh and London, p.1-560. 